The Unsung Impact of Currency Risk on the Performance of International Real Property Investment

By

Kwame Addae-Dapaah*

Tan Yong Hwee, Wilfred ${ }^{+}$

* Department of Real Estate, SDE, NUS, Singapore

${ }^{+}$URA, Singapore.

JEL Classification Codes: C20 (General Econometric Methods)

C73 (Stochastic and Dynamic Games)

F21 (International Investment)

F31 (Foreign Exchange)

G11 (Portfolio Choice)

R33 (Nonagricultural and Nonresidential Real Estate Markets)

Please send all correspondence to:

Kwame Addae-Dapaah

Department of Real Estate

School of Design \& Environment

National University of Singapore

4 Architecture Drive

Singapore 117566

Tel: (65) 65163417 Fax: (65) 67748684

E-Mail: rstka@nus.edu.sg

Published in Review of Financial Economics, 18 (2009): 56-65. (United States). Doi:10.1016/j.rfe.2008.04.002 


\title{
The Unsung Impact of Currency Risk on the Performance of International Real Property Investment
}

\begin{abstract}
The paper revisits the currency risk debate to ascertain the statistical significance of currency risk on the return of international real property investment, especially in a period of increased exchange rate volatility. After statistical analyses of the returns of a portfolio of office investments in seven Asia Pacific cities over the 1986 to 2007 period, it was found that currency risk had a statistically significant positive impact on the performance of the portfolio of office investments. This is confirmed by the results of stochastic dominance test. If the results of this study are verified by subsequent studies, and the past reliably presages the future, they would imply that investors holding portfolios of real property investments in the sample markets might not need to be unduly concerned with currency risk.
\end{abstract}

Key words: Currency risk, Asia Pacific, portfolio, investment, return, real property.

\section{Introduction}

International investment in property has become a persistent feature of real estate markets in the developed economies. Real estate investors and advisers increasingly act in a global capacity. Cross border activity means that real estate investment must focus not only on cash flow patterns - changes in rents and capital values - but also on the impact of currency movement. Incorporating exchange rate volatility into the analysis of an international investment can substantially alter the expected return and risk characteristics of the investment (see Sirmans and Worzala, 2003). Although several studies have concluded that currency risk does not have statistical significant effect on the performance of a diversified international real estate portfolio, investors' concern over the ravages of currency risk (see Newell and Worzala, 1995; Balogh and Sultan, 1997) has led to experimentation with various means of hedging international real property investment returns (see for example, Delaney, 1987; Ziobrowski and Ziobrowski, 1993 \& 1995; Worzala et al. 1997; Johnson et al. 2002). However, it has been shown 
mathematically that currency risk cannot be completely hedged away (McGowen et al. 1987) notwithstanding the cost of currency hedging.

Therefore, the paper revisits the currency risk debate with the objective of ascertaining the significance of exchange rate movements on the performance of a portfolio of international real estate investments especially in a period of increased exchange rate fluctuation and uncertainty. Specifically, it is hypothesized that currency risk has a significant negative impact on US dollar-denominated portfolio of international office property investments. This is operationalised through statistical tests of the results of an empirical study of office investments in seven Asia Pacific cities (including cities that were severely affected by the Asian currency crisis) over the period 1986Q2-2007Q3 inclusive. This study differs from others by analyzing data for before, during and after, the Asia currency crisis period.

The next section therefore provides a brief review of a selected relevant literature. This is followed by a discussion of data sourcing and management after which the analyses, interpretation and discussion of the results are presented. The final section deals with concluding remarks.

\section{Literature Review}

The benefits of international diversification are comprehensively documented in the literature. For example, Levy and Sarnat (1970), Ripley (1973), Solnik (1974), Jorion (1985), Gordon (1991), Sweeney (1993), Barry and Lockwood (1995) and Solnik and McLeavey (2003), to name a few, have concluded that international portfolios provide higher returns with lower variances than purely domestic portfolios due to low correlations between different national economies. This appears to be the general consensus of past researchers notwithstanding Goetzmann et al's (2001) contention, which has been controverted by Forbes and Rigobon (2002), that the benefits of international diversification are overstated. However, the return from an international portfolio (whether the benefits are overstated or not), is exposed to currency risk as a 
result of the investor owning a claim in a foreign currency-denominated, time-deferred cash flow (Jacque, 1996).

\section{Currency Risk}

Exchange rates movements have serious implications on the profitability of international real estate investments through the interplay of movements between the investor's home country currency and the foreign currency. Balogh and Sultan (1997) reported that fluctuating exchange rate is the most common risk of overseas investment. According to Ziobrowski and Curcio (1991) and Radcliffe (1994), the exchange rate risk of investments made in a single foreign country can be substantial (see also Ziobrowski and Boyd, 1991; Ziobrowski and Ziobrowski, 1993). This conclusion has been concurred by Worzala (1995). Similarly, Newell and Webb (1996) found the contribution of currency risk to the risk profile of an international mixed-asset portfolio to be significant for the period 1985-1993. This additional risk was particularly evident in real estate and bonds the impact of currency risk on stocks was only marginal compared to real estate and bonds.

However, Jorion (1990) concluded that from an investor's viewpoint, exchange rate exposure would be important only if it represented a significant component of an asset's risk. Similarly, Solnik (1996) argued that currency fluctuation has never been the major component of total return on a diversified portfolio over a long period of time because the depreciation of one currency is often offset by the appreciation of another (see Biger, 1979; Addae-Dapaah and Choo, 1996; Addae-Dapaah and Goh, 1998). This supports Froot (1993) who concluded that the contribution of currency risk to the total return of an international diversified portfolio winnows out over time. Solnik and McLeavey (2003) replicated this finding by concluding that the contribution of currency risk decreases with the length of the investment horizon as exchange rates tend to revert to the mean. 
Notwithstanding the disagreement on the impact of exchange rate volatility on the returns of foreign investments, currency risk management is considered to be the most important area of risk management in international investment (Solnik, 1996), especially if the exchange rate exposure is significant. In view of this, there has been considerable interest, among researchers, in exploring currency-hedging possibilities to mitigate the currency risk of an international real estate investment. This presupposes that exchange rate volatility has a significant negative impact on foreign real estate investment returns. Since this is not conclusively proven, the basic hypothesis of this paper is that exchange rate volatility has a statistically significant impact (positive or negative) on the returns of a portfolio of international real property investments.

\section{Data Sourcing and Management}

Ex-post quarterly data of office capital and rental values for seven Asia Pacific cities: Singapore, Kuala Lumpur, Tokyo, Hong Kong, Makati, Melbourne and Jakarta, were extracted from Jones Lang LaSalle Asia Pacific Property Digest. The choice of the cities (especially Tokyo, Hong Kong and Melbourne) was based on the availability of data. Moreover, Singapore, Kuala Lumpur, Makati and Jakarta were selected for the study for being the cities that were mostly affected by the Asian currency crisis. In addition, quarterly market exchange rates were obtained from DataStream and Bloomberg databases. These exchange rates are used to convert all foreign office investment returns (in local currency) to US dollar returns.

The study covers a period of twenty-one and a half years from 1986Q2 to 2007Q3 inclusive (Period 1). This period is subdivided into two: pre-Asian Financial Crisis 1986Q2 to 1995Q4 (Period 2) - and post-Asian Financial Crisis - 1996Q1 to 2007Q3 (Period 3). Period 3 is further divided into two sub-periods: 1996Q1 to 1998Q4 (Period 4 
- period of the Asian Financial crisis) and 1999Q1 to 2007Q3 (Period 5 - the actual postAsian Financial crisis era).

Furthermore, the following assumptions are made to facilitate the testing of the hypothesis:

1) The portfolio of investments consists of office properties only (due to data constraint).

2) The investor has/can raise sufficient funds for his investments in office properties. This assumption is aimed at circumventing the problem of capital rationing.

3) The investor adopts the mean-variance approach in investments; i.e. he is rational and seeks to attain Markowitz's efficient investments lying on the efficient frontiers.

4) All funds invested in foreign office properties will be repatriated to the home country at the end of the holding period (i.e. each quarter). The assumption of quarterly repatriation of returns is certainly preposterous for investment in real estate. However, if currency risk ever has a significant devastating effect on international property investment, the assumption of quarterly repatriation of returns (although seemingly unrealistic) may be the best way to detect the effect. If the assumption leads to a finding that currency risk has a statistically significant negative impact on property portfolio returns, sensitivity analyses will be conducted by relaxing the quarterly repatriation of returns in favour of 5 and 10-yearly repatriation of capital returns and annual repatriation of rental returns. However, there will be no need for further analyses if the results show that currency risk does not have significant negative impact on property returns as currency risk is more devastating in the short, than in the long, term. In view of this assumption, capital gains tax is ignored in all the analyses as accounting 
for it would grossly distort the results. The reason for this is that there are penal capital gains tax rules and other taxes for the disposal of property within five years in some countries (e.g. Malaysia, New Zealand and Hong Kong) where such taxes would not be applicable under normal circumstances. Although quarterly holding period is assumed for the analyses, it is reasonable to state that in reality, astute investors would play within the tax laws to avoid paying "unnecessary" taxes. At any rate, no real property investor will liquidate his assets quarterly albeit the analyses are premised on quarterly holding periods - the assumption is made purely to facilitate detection of the ravages of currency risk, if any. Thus, the reader must take note of the caveat that the paper does not account for tax, except property tax.

\section{Currency Unadjusted Returns from Office Investment}

The data are used to calculate the quarterly holding period currency unadjusted office investment returns. The quarterly returns are averaged over the full study period to determine the time-weighted average return (Exhibit 1) - Arithmetic mean is most widely used in portfolio analyses (Geltner and Miller, 2001). Furthermore, arithmetic mean is supposed to be more accurate than geometric mean for estimating average performance across different securities for one period as well as being an unbiased estimate of future expected rates of return (Levy, 1996).

\section{Exchange Rate Return}

A foreign real estate investor, in effect, makes two investments: investment in real property (office property in this case), and investment in foreign currency. Thus, in addition to the currency unadjusted office investment returns, the quarterly market exchange rates data are used to calculate the expected holding period exchange rate returns for each city in the sample (see Exhibit 2). 


\section{Currency Adjusted Returns}

Since the return from an international investment is a composite of the foreign currency denominated returns and exchange rate returns, the currency adjusted foreign office investment returns are expressed as:

$$
\begin{aligned}
& R_{\text {adj }}=R_{t}+X_{t}\left(1+R_{t}\right) \\
& \text { where: } \\
& R_{\text {adj }}=\text { Currency adjusted foreign investment returns } \\
& R_{t}=\text { Currency unadjusted rate of return for period } t \\
& X_{t}=\text { Percentage change in exchange rates }
\end{aligned}
$$

The expected quarterly currency unadjusted and adjusted office investment returns are presented in Exhibit 1. The quarterly return figures are used to calculate the correlation of returns presented in Exhibit 5.

\section{Statistical Testing of Impact of Currency Risk on Foreign Office Returns}

To test the null hypothesis that there is no difference between the currency-adjusted and unadjusted mean returns for single foreign-country office investment $\left(H_{0}: \overline{R_{a}}=\overline{R_{u}}\right)$, the following test statistic (Triola, 1997) is used:

$$
Z=\frac{\overline{R_{a}}-\overline{R_{u}}-\left(\mu_{a}-\mu_{u}\right)}{\sqrt{\frac{\sigma_{a}^{2}}{N_{a}}+\frac{\sigma_{u}^{2}}{N_{u}}}} \sim N(0,1),
$$

Where:

$$
Z=\text { Test statistic } \sim N(0,1)
$$

$\overline{R_{a}}, \overline{R_{u}}=$ Expected return after and before currency adjustment

$\mu_{a}, \mu_{u}=$ Population mean after and before currency adjustment

$N_{a}, N_{u}=$ Sample size for currency adjusted and unadjusted return

$\sigma_{a}^{2}, \sigma_{u}^{2} \quad=$ Variance for currency adjusted and unadjusted return 
A two-tailed z-statistic performed at the 5\% significance level will reject the null hypothesis if the test statistic falls into the critical region of $>1.96$ or $<-1.96$.

\section{Statistical Testing of Impact of Currency Risk on Correlation Coefficients}

The correlation coefficients are transformed via the Fisher transformation (Myers, 2003) to produce a function that is normally distributed rather than skewed.

$$
\begin{aligned}
& Z_{i j}(k)=\frac{1}{2} \ln \left(\frac{1+\rho_{i j}}{1-\rho_{i j}}\right) \text { (Equation 3) } \\
& \text { subject to }-1<\rho_{i j}<1 \\
& \text { where } Z_{i j}(k)=\text { Fisher transformation } \\
& \rho_{i j} \quad=\text { Correlation coefficient between asset } i \text { and } j \\
& k \quad=\text { Currency adjusted }(a) \text { and unadjusted }(u) \text { correlation coefficient }
\end{aligned}
$$

To test the null hypothesis that there is no difference between currency-adjusted and unadjusted correlation coefficients $\left(H_{0}: \rho_{1}=\rho_{2}\right)$, the test statistic, denoted by $Z_{i j}$, is used.

$$
\begin{gathered}
Z_{i j}=\frac{Z_{i j}(a)-Z_{i j}(u)}{\sqrt{\frac{1}{N_{a}-3}+\frac{1}{N_{u}-3}}} \sim N(0,1) \\
\text { where } Z_{i j}(k)=\text { Fisher transformation (Equation 3) } \\
N_{k} \quad=\text { Sample size }
\end{gathered}
$$

A two-tailed $\mathrm{z}$-statistic performed at a 5\% significance level will reject the null hypothesis if the test statistic falls into the critical region of $>1.96$ or $<-1.96$. 


\section{Optimal Portfolios and Efficient Frontiers}

Markowitz's mean variance approach is used to construct the optimal portfolios which are the bases of the efficient frontiers (Exhibits 8a-c) presented in the studies. It must be noted that short-selling has not been allowed in the calculation of portfolio risk (equation 5) as it is not possible to short-sell direct property investment.

$$
\begin{aligned}
& \sigma_{\text {port }}=\sqrt{\sum_{i=1}^{n} w_{i}^{2} \sigma_{i}^{2}+\sum_{i=1}^{n} \sum_{j=1}^{n} W_{i} W_{j} \rho_{i j} \sigma_{i} \sigma_{j}} \\
& \text { subject to } W_{i} \geq 0 \text { (no short sales allowed) and } \sum_{i=1}^{n} W_{i}=1 \\
& \text { where } \sigma_{p o r t} \quad=\text { Risk of portfolio; } \\
& \sigma_{i}, \sigma_{j}=\text { Standard deviation of assets } i \text { and } j \text { respectively; } \\
& W_{i}, W_{j}=\text { Weights of the individual assets } i \text { and } j \text { respectively; and } \\
& \rho_{i j} \quad=\text { Correlation coefficient between asset } i \text { and } j .
\end{aligned}
$$

\section{Impact of Currency Risk on Portfolio Expected Returns}

The Paired $t$-test is used to test the null hypothesis that there is no difference between the currency adjusted and unadjusted portfolio expected returns and risk.

$$
\begin{aligned}
& H_{0}: \overline{R_{\text {port }, a}}=\overline{R_{\text {port }, u}} \\
& H_{1}: \overline{R_{\text {port }, a}} \neq \overline{R_{\text {port }, u}} ; \text { and } \\
& H_{0}: \overline{\sigma_{\text {port }, a}}=\overline{\sigma_{\text {port }, u}} \\
& H_{1}: \overline{\sigma_{\text {port }, a}} \neq \overline{\sigma_{\text {port }, u}}
\end{aligned}
$$

A two-tailed $t$-statistic performed at the $5 \%$ level of significance will reject the null hypothesis if the test statistic falls into the critical region of $>2.262$ or $<-2.262$. If the above tests show that currency risk had favorable impact on portfolio performance, stochastic dominance will be used to ascertain the beneficial impact of exchange rate volatility. 


\section{Stochastic Dominance}

An alternative approach to the mean-variance model for evaluating investments is the stochastic dominance $(S D)$ analysis, which has been employed in various areas of economics, finance and statistics (Levy, 1992; Al-khazali, 2002; Kjetsaa and Kieff, 2003). The efficacy and applicability of $S D$ analysis, and its relative advantages over the mean-variance approach, have been discussed and proven by several researchers including Hanoch and Levy (1969), Hadar and Russell (1969), Rothschild and Stiglitz (1970), Whitmore, 1970, Levy (1992 \& 1998), Alkhazali (2002) and Barrett and Donald (2003). According to Porter et al. (1973:71), SD has been shown to be theoretically superior to all these "moment methods"". Taylor and Yodder (1999), state that $S D$ is a theoretically unimpeachable general model of portfolio choice that maximizes expected utility. Kuosmanen (2001) suggests that $S D$ is attractive because it is effectively nonparametric as no explicit specification of a utility function or probability distribution functional form is required. Similarly, Meyer et al. (2005:149) state that "SD is theoretically superior to mean-variance analysis because it considers the entire return distribution and is based on minimally restrictive assumptions regarding investor motives."

\section{Stochastic Dominance Criteria}

The $S D$ rules are normally specified as first, second, and third degree $S D$ criteria denoted by FSD, SSD, and TSD respectively (see Levy, 1992; Barrett and Donald, 2003; Barucci, 2003). There is also the nth degree $S D$. Given that $F$ and $G$ are the cumulative distribution functions of two mutually exclusive risky options $X$ and $Y, F$ dominates $G(F D G)$ by $F S D, S S D$, and $T S D$, denoted by $F D_{1} G, F D_{2} G$, and $F D_{3} G$, respectively, if and only if,

$$
\begin{array}{lll}
F(X) \leq G(X) & \text { for all } X(F S D) & \text { (Equation 6) } \\
\int_{-\infty}^{x}[G(t)-F(t)] d t \geq 0 & \text { for all } X(S S D) & \text { (Equation 7) } \\
\int_{-\infty}^{x} \int_{-\infty}^{v}[G(t)-F(t)] d t d v \geq 0 & \text { for all } X, \text { and } \\
E_{F}(X) \geq E_{G}(X)(T S D) & \text { (Equation 8) }
\end{array}
$$

The FSD (also referred to as the General Efficiency Criterion - Levy and Sarnat, 1972) assumes that all investors prefer more wealth to less regardless of their attitude towards risk. The $S S D$ is based on the economic notion that investors are risk averse while the TSD posits that investors exhibit decreasing absolute risk aversion (Kjetsaa and Kieff, 2003). A higher 
degree $S D$ is required only if the preceding lower degree $S D$ does not conclusively resolve the optimal choice problem. Thus, if $F D_{l} G$, then for all values of $x, F(x) \leq G(x)$ or $G(x)-F(x) \geq 0$. Since the expression cannot be negative, it follows that for all values of $x$, the following must also hold:

$$
\int_{-\infty}^{x}[G(t)-F(t)] d t \geq 0 ; \text { that is, } F D_{2} G \text { (Levy and Sarnat, 1972) }
$$

Furthermore, the $S D$ rules and the relevant class of preferences $U_{i}$ are related in the following way:

$$
\begin{array}{cc}
\text { FSD: } F(X) \leq G(X) \forall X \Leftarrow \Rightarrow E_{F} U(X) \geq E_{G} U(X) & \forall u \in U_{1}, \\
\text { SSD: } \int_{-\infty}^{x} F(t) d t \geq \int_{-\infty}^{x} G(t) d t \forall X \Leftarrow \Rightarrow E_{F} U(X) \geq E_{G} U(X) & \forall u \in U_{2}, \\
\text { TSD: } \int_{-\infty}^{x} \int_{-\infty}^{v} F(t) d t d v \geq \int_{-\infty}^{x} \int_{-\infty}^{x} G(t) d t d v \forall X \Leftarrow \Rightarrow E_{F} U(X) \geq E_{G} U(X) \\
\forall u \in U_{3} \text {, and } \\
E_{F}(X) \geq E_{G}(X),
\end{array}
$$

where $U_{i}=$ utility function class $(i=1,2,3)$

$U_{1}$ includes all $u$ with $u^{\prime} \geq 0$;

$U_{2}$ includes all $u$ with $u^{\prime} \geq 0$ and $u^{\prime \prime} \leq 0$; and

$U_{3}$ includes all $u$ with $u^{\prime} \geq 0, u^{\prime \prime} \leq 0$ and $u^{\prime \prime \prime} \geq 0$.

In other words, a lower degree $S D$ is embedded in a higher degree $S D$. The economic interpretation of the above rules for the family of all concave utility functions is that their fulfilment implies that $E_{F} U(x)>E_{G} U(x)$ and $E_{F}(x)>E_{G}(x)$; i.e. the expected utility and return of the preferred option must be greater than the expected utility and return of the dominated option.

\section{Empirical Results - Currency Risk and Office Investment Return}

The expected quarterly currency unadjusted (u) and adjusted (a) office property returns are presented in Exhibit 1. The results in Exhibit 1 show that currency risk had a predominantly negative impact on office property returns. However, the negative effects 
of currency risk on each city's investment returns varied from period to period to reflect the corresponding changes in the economic fundamentals of the cities.

\section{Exhibit 1}

Over the entire period (i.e. Period 1), exchange rate fluctuation considerably reduced the office investment returns for four of the seven cities - Jakarta suffered the highest reduction $(-98.04 \%)$ in return from $+3.58 \%$ (unadjusted) to $+0.07 \%$ (adjusted). Tokyo experienced the highest percentage increase of $44.9 \%$ (from $+0.69 \%$ to $1.00 \%$ ) and $378.43 \%$ (from $0.44 \%$ to $2.09 \%$ ) in the office property return during Periods 1 and 2 respectively (Exhibit 1).

The ravages of the exchange rate volatility were pronounced in Periods 3 and 4. Makati ( $1506.25 \%$ decline from $0.16 \%$ to $-2.25 \%)$ and Kuala Lumpur (307.68\% fall from $1.27 \%$ to $-2.64 \%$ ) suffered the highest reduction in returns in Periods 3 and 4 respectively (Exhibits 1 and 2). In contrast, Kuala Lumpur experienced the highest increase $(82.86 \%$ from $0.35 \%$ to $0.64 \%$ ) in office property return, as a result of exchange rate volatility, in Period 5. It could be seen from Exhibit 1 that the returns for Makati were ravaged by currency risk in every period. Similarly, the returns for Jakarta were ravaged by currency risk in every period except Period 5 where it experienced increased returns attributable to exchange rate volatility. Periods 4 and 5, in particular, were fraught with heightened uncertainties precipitated by the Asian currency crisis, the 9/11 terrorist attack, Bali bombing and the SARS epidemic. The results generally show that exchange rate fluctuations had negative impact on currency adjusted office returns especially in the turbulent periods of extreme economic uncertainty (i.e. Periods 3 and 4). However, these effects are found to be statistically insignificant (Exhibit 4).

\section{Exhibit 2}

\section{Exchange Rate Volatility and Office Investment Risk}

The results presented in Exhibit 3 reveal that currency risk predominantly had detrimental effects on the office investment risk for all the periods. Jakarta recorded the highest favorable impact (i.e. reduction in standard deviation) of currency risk $(-37.48 \%$ and $38.34 \%$ respectively in Periods 5 and 1) while Melbourne experienced the worst 
detrimental effect (i.e. increase in standard deviation) of exchange rate volatility $(+103.02 \%$ in Period 5). However, both the favorable and unfavorable effects are statistically insignificant.

\section{Exhibit 3}

Similarly, exchange rate volatility predominantly had detrimental/favorable effects on risk in Periods 1, 3 and 5/2 and 4 (the period of Asian currency crisis) when risk is considered in relative terms (i.e. in terms of coefficient of variation - CV) instead of in absolute terms (i.e. standard deviation) - see Exhibit 3. In terms of CV, office investments in Singapore, Hong Kong and Makati (in descending order) were the safest markets in Period 1. Jakarta was the riskiest market in Period 1, followed by Melbourne, in terms of currency adjusted CV. However, Jakarta and Makati paradoxically emerged as the second safest and the safest office markets respectively in Periods 2 and 3 (in terms of currency adjusted $\mathrm{CV}$ - subject to the quarterly returns being negative). Even during the period of extreme exchange rate volatility (Period 4), Jakarta paradoxically emerged as the safest (predicated upon currency adjusted CV) office market while Makati was the third safest market.

The safeness of these markets is paradoxical as the relatively low CVs are based on negative mean returns (i.e. losses) and thus, are very delusory. A loss is a loss by any means to render the corresponding investment risky no matter how low the $\mathrm{CV}$ is. Given some negative mean returns, the CVs do not make sense (see Livers, 1942). This implies that "safeness" of a market(s) on the basis of CV does/do not necessarily mean that the market(s) provide(s) better investment prospects. Thus, Melbourne, Singapore, Tokyo

and Hong Kong which, in contradistinction, appears to be relatively risky (courtesy of $\mathrm{CV}$ ) albeit registering more positive returns (compare Exhibits 1 and 3) are far safer than Jakarta and Makati. However, the results presented in Exhibit 4 (based on Equation 2) reveal no significant difference, at the 0.05 level, between the currency unadjusted and adjusted mean returns for each city.

\section{Exhibit 4}




\section{Currency Risk and Correlation Coefficients of Office Returns}

The correlation coefficients of the currency unadjusted and adjusted office market returns

are presented in Exhibit 5. Generally, the entire markets exhibit relatively low positive and negative correlations for every period under consideration. Currency risk reduced 76.19\% (Period 1), 47.61\% (period 2), 61.9\% (Period 3), 42.86\% (Period 3) and 66.67\% (Period 5) of the inter-country correlation coefficients. Moreover, currency risk had favorable impact on (i.e. reduced) the inter-country correlation coefficients for almost every period (highlighted in Exhibit 5) for some cities in the sample. Most of the statistically significant reductions in the correlation coefficients as a result of currency rate fluctuations occurred in Period 4 (Exhibit 5) - the period of Asian currency crisis. In addition, Tokyo-Makati recorded more statistically significant reductions in their currency adjusted correlations (Periods 3-5 of Exhibit 5) than the remaining inter-city combinations. However, exchange rate fluctuation markedly increased the correlation between Kuala Lumpur and Jakarta, and Tokyo and Jakarta during Period 4. The teststatistic, notwithstanding, reveals that there is virtually no difference between the currency unadjusted and adjusted correlation coefficients (Exhibit 5) especially for Period 1.

\section{Exhibits 5 \& 6}

There is only one significant test-statistic each for Periods 2 and 5 (Tokyo-Melbourne) and Period 3 (Hong Kong-Tokyo), and three significant test-statistics for Period 4 (see Exhibit 6). These figures augur a great potential for diversification benefits. Whether the generally marginal differences between the currency unadjusted and adjusted correlation coefficients may translate into a significant difference between the currency unadjusted and adjusted returns of a diversified portfolio is yet to be seen.

\section{Correlation Coefficients of Exchange Rate Returns}

The figures in (Exhibit 7) show that the inter-city correlation coefficients of exchange rate returns are relatively very low. The only relatively high correlations of exchange rate returns in Period 1 are for Singapore-Kuala Lumpur (0.607) and Singapore-Tokyo (0.645). These two-pair markets exhibit relatively high correlations for all the periods 
under consideration. This implies that investing in these markets may not result in significant reduction of exchange rate risk.

\section{Exhibit 7}

It is worth noting that the correlation coefficient between Melbourne and every other city is virtually negative for every period of analysis (Exhibit 7). This implies that including Melbourne in a diversified portfolio consisting of office investments in any of these cities could be very beneficial in reducing currency risk.

\section{Optimal Portfolios and Efficient Frontiers}

Matlab was used to generate the optimal portfolio compositions (available from authors) which are the bases of the efficient frontiers for Periods 1, 4 and 5 (see Exhibits 8a-c) The efficient frontiers for Periods 2 and 3, which are similar to those presented in the paper, are available from the authors. It is evident from Exhibits 8a-c that the currency adjusted efficient frontiers $\left(\mathrm{C}_{\mathrm{ap}}\right)$ dominate the currency unadjusted frontiers $\left(\mathrm{C}_{\text {up }}\right)$ even in Periods 4 and 5 when there was much turbulence in the currency markets of most of the sampled cities.. This implies that exchange rate volatility had beneficial effects (the unsung impact) on the performance of a portfolio of office investments in the sampled markets.

\section{Exhibits 8a-c}

Moreover, Exhibit 9 reveals that the return and risk for the currency adjusted portfolio are statistically higher (at conventional levels of significance) than the currency unadjusted portfolio for all the periods except Period 5 where there is no statistical difference between the returns for both portfolios. Thus, the hypothesis that currency risk has a statistically significant negative impact on US dollar-denominated portfolio of international office investments is rejected. Currency risk during the periods certainly had statistically significant effect on portfolio returns - The effect, which is contrary to expectation, was positive rather than negative. It must be noted, however, that the statistically significant higher currency adjusted portfolio return was a compensation for a 
correspondingly higher currency adjusted portfolio risk during the periods under investigation. This finding, which contrasts Addae-Dapaah and Choo (1996) and AddaeDapaah and Goh (1998), may imply that the choice between the currency unadjusted and adjusted portfolios is a function of one's risk appetite.

Therefore $S D$ is employed to decide the economically preferred option. The reason for resorting to $S D$ is that it has been found to be a theoretically unimpeachable general model of portfolio choice that maximizes expected utility (Taylor and Yodder, 1999). Furthermore, Meyer et al. (2005:149) has been quoted earlier on in the paper (see section on Stochastic Dominance) as stating that " $S D$ is theoretically superior to mean-variance analysis because it considers the entire return distribution and is based on minimally restrictive assumptions regarding investor motives."

\section{Exhibits 9}

The results of the $S D$ tests that are presented in Exhibits 10a-c (based on the currency unadjusted and adjusted portfolio returns) clearly reveal that $\mathrm{C}_{\mathrm{ap}} \mathrm{D}_{1} \mathrm{C}_{\mathrm{up}}-$ i.e. currency adjusted portfolio stochastically dominates currency unadjusted portfolio by $F S D$ even during the most turbulent and uncertain economic periods (i.e. Periods 4 and 5). This implies that currency adjusted portfolio stochastically dominates currency unadjusted portfolio by $F S D, S S D$ and TSD. In other words, the currency adjusted portfolio provides a higher probability of receiving a return that is greater than, or equal to, a given portfolio return than currency unadjusted portfolio. This implies that the currency adjusted portfolio statistically augured a higher probability of success than its currency unadjusted counterpart during the periods under consideration.

For example, the results in Exhibit 10a show that there was a $90 \%$ probability that the currency adjusted portfolio would provide a quarterly return of not less than $1.11 \%$ whereas the probability of the currency unadjusted portfolio providing the same return was $70 \%$. Similar results are obtained for periods of extreme turbulence in the currency markets (Periods 4 and 5). The probabilities for obtaining a quarterly return of not less 
than $2.03 \%$ during Period 4 (Exhibit 10b) were $80 \%$ and $70 \%$ respectively for currency adjusted and unadjusted portfolios. In Period 5 (Exhibit 10c), the probability for the currency adjusted portfolio providing a quarterly return that was equal to, or more than, $1.28 \%$ was $30 \%$ compared to $10 \%$ for the currency unadjusted portfolio. Thus, the currency adjusted portfolio should have been preferable to both risk averters and risk lovers (Kjetsaa and Kieff, 2003) as it provided a higher expected utility (i.e. return) than the currency unadjusted portfolio. This means that currency risk benefited investors who held a portfolio of office investments in the sampled cities during the study periods.

\section{Exhibits 10a-c}

\section{Conclusion}

The paper set out to examine the impact of currency risk on the performance of international office investments in seven Asia Pacific cities. While the results of the study reveal that currency risk generally reduced/increased office investment return/risk for the individual sampled cities, there is no statistical difference between the currency unadjusted and adjusted office investment return/risk. Similarly, the results show that there is no statistical difference between the currency unadjusted and adjusted inter-city correlation coefficients albeit currency conversion predominantly reducing the correlation coefficients (positive impact).

However, the results at the portfolio level, is contrary to both expectation and extant literature - exchange rate fluctuation had a positive (instead of negative) impact on the performance of an international diversified portfolio of office investments in the sampled cities for the entire period and sub-periods, which include periods of extreme turbulence in the currency markets of the sampled cities. The positive (i.e. unsung) impact on the portfolio returns, which is statistically significant at the 0.05 level of significance, is confirmed by stochastic dominance tests. The implication of the results of the study (if the results can be generalized in any way, and the past could be a credible augury of the future) is that office investors, who are holding a diversified portfolio of office investments in the sampled cities, may not be unduly concerned with currency risk as it could work in their favor. The relatively low and negative correlations among the 
exchange rate returns of the sampled cities provide more than a natural hedge against currency risk. This implies that any attempt to hedge the portfolio returns could be doubly costly - the cost of the hedging instrument and the loss of the "unsung" beneficial effects of currency movements - and thus inadvisable. It must be reiterated that the foregoing conclusion is based on a portfolio of investments in the sampled cities. Any investor who invests in any one of the sampled cities (especially at a time when the currency of the sampled city is strong) may have to be concerned with currency risk.

\section{Reference}

Addae-Dapaah, K. and B. K. Choo (1996) International Diversification of Property Stock - A Singaporean Investor's Viewpoint. Real Estate Finance, 13(3), 54-66.

Addae-Dapaah, K., and Goh, L.Y. (1998). Currency Risk and Office Investment in Asia Pacific. Real Estate Finance, 15(3), 67-85.

Al-Khazali, O. (2002) Stochastic Dominance as a Decision Technique for Ranking Investments. Academy for Economics and Economic Education, 5(1), 1-8.

Balogh, C. and J. Sultan (1997) Investing in Foreign Real Estate: A Primer. Real Estate Review, Spring, 73-80.

Barrett, G. F. and Donald, S. G. (2003) Consistent Tests for Stochastic Dominance. Econometrica, 71(1), 71-104.

Barry, C.B. and L.J. Lockwood (1995) New Directions in Research on Emerging Capital Markets. Financial Markets, Institutions \& Instruments, 4(5), 15-36.

Barucci, E. (2003) Financial Markets Theory: Equilibrium, Efficiency and Information. London: Springer.

Biger, N. (1979) Exchange Rate Implications of International Portfolio Diversification, Journal of International Business Studies, Fall, 64-74.

Delaney, G. (1987) Foreign Currency Options and International Rental Income - A Japanese Study, International Real Estate Journal, 14(1), 7-10.

Forbes, K. and R. Rigobon (2002). No Contagion, Only Interdependence: Measuring 
Stock Market Co-movements. Journal of Finance, 57 (5), 2223-2261.

Froot, K.A. (1993) Currency Hedging over Long Horizons. National Bureau of Economic Research, Working Paper No. 4355, 1-40.

Geltner, D. and N. Miller (2001), Commercial Real Estate Analysis and Investments. NJ: Prentice Hall.

Goetzmann, W., Li, L., and Rouwenhorst, G. (2001). Long-Term Global Market Correlation, Working Paper.

Hadar, J. and W. R. Russel (1969) Rules for Ordering Uncertain Prospects. American Economic Review, 59, 25-34.

Hanoch, G. and H. Levy (1969) The Efficiency Analysis of Choices Involving Risk. The Review of Economic Studies, 36:3, 335-346.

Hoesli, M., J. Lekander, and W. Witkiewicz (2002) International Evidence on Real Estate as a Portfolio Divisifier. Working Paper.

Jacque, L. L. (1996). Management and Control of Foreign Exchange Risk. Norwell, MA: Kluwer Academic Publishers.

Johnson, R., E. Worzala, and C. Lizieri (2002). Currency Swaps for Hedging a Realistic International Real Estate Investment: Do they Work? Working Paper Series, University of Reading.

Jorion, P. (1985) International Portfolio Diversification with Estimated Risk. Journal of Business, 58, 259-278.

Kjetsaa, R. and M. Kieff (2003) Stochastic Dominance Analysis of Mutual Fund Performance. American Business Review, 21(1), 1-8.

Kuosmanen, T. (2001). Stochastic Dominance Efficiency Tests Under Diversification. Helsinki School of Economics Working Paper W-283.

(2004). Efficient Diversification According to Stochastic Dominance Criteria. Management Science, 50(10): 1390-1406.

Levy, H., Stochastic Dominance and Expected Utility: Survey and Analysis. Management Science, 1992, 38:4, 555-593.

Publishers. (1996). Introduction to Investments. Cincinnati, Ohio: South-Western College 
(1998). Stochastic Dominance: Investment Decision Making Under Uncertainty. Boston: Kluwer Academic Press.

Levy, H. and M. Sarnat, Investment and Portfolio Analysis, New York: Wiley and Sons, 1972.

Livers, J.J. (1942) Some Limitations to Use of Coefficient of Variation, Journal of Farm Economics, 24(4), 892-895.

Lizieri, C., E. Worzala and R. Johnson (1998). To Hedge or Not To Hedge. London: Royal Institution of Chartered Surveyors.

Markowitz, H.M. (1952). Portfolio Selection. Journal of Finance, 7 (1), 77-91.

McGowan, C. B. Jr., P. Asabere, and H. W. Collier, Limitations of Using Foreign Exchange Rate Hedges to Cover Foreign Real Estate Investments, International Real Estate Journal, 1987, 13:1, 78-81.

Meyer, T. O., X. M. Li and L. C. Rose (2005). Comparing Mean Variance Tests with Stochastic Dominance Tests When Assessing International Portfolio Diversification Benefits. Financial Services Review, 14(2): 149-169.

Myers, J.L., and A.D. Well (2003). Research Design and statistical analysis. ( ${ }^{\text {nd }}$ ed.,). New Jersey: Lawrence Erlbaum Associates, Inc., Publishers.

Newell, G. and E. Worzala (1995). The Role of international property in investment Portfolios. Journal of Property Finance, 6 (1), 55-63.

Newell, G. and J. Webb, Assessing Risk for International Real Estate Investments, Journal of Real Estate Research, 1996, 11(2), 103-115.

Porter, R.B., J.R. Wart and D.L. Ferguson (1973). Efficient Algorithms for Conducting Stochastic Dominance Tests on Large Numbers of Portfolios. Journal of Financial and Quatitative Analysis, 8, 71-81.

Radcliffe, R.C., Investment: Concepts, Analysis, Strategy, New York: HarperCollins College Publishers, fourth edition, 1994.

Rothschild, D. and J. E. Stiglitz (1970). Increasing Risk I: A Definition. Journal of Economic Theory, 2, 225-243.

Sirmans, C.F. and E. Worzala (2003). International Direct Real Estate Investment: A Review of the Literature. Urban Studies, 40 (5-6), 1081-1114.

Solnik, B., International Investments, Massachusetts: Addison-Wesley, third edition, 1996. 
Solnik, B.H. and D. McLeavey (2003). International investments. (5 ${ }^{\text {th }}$ ed.,). Boston : Addison-Wesley.

Taylor, W. and J. Yoder (1999) Load and No-Load Mutual Fund Dynamics During the 1987 Market Crash. Journal of Economics and Finance, 23, 155-165.

Whitmore, G. A. (1970) Third Degree Stochastic Dominance. American Economic Review, 60, 457-459.

Worzala, E. (1995). Currency risk and international property investments. Journal of Property Valuation and Investment, 13 (5), 23-28.

Worzala, E.M., Johnson, R.D. and Lizieri, C.M. (1997). Currency swaps as a hedging technique for an international real estate investment. Journal of Property Finance, 8 (2), $134-151$.

Ziobrowski, A and J. Boyd (1991). Leverage and foreign investment in US real estate. Journal of Real Estate Research, 7 (1), 33-58.

Ziobrowski, A and R. Curcio (1991). Diversification benefits of US real estate to foreign investors. Journal of Real Estate Research, 6 (2), 119-142.

Ziobrowski, A and B. Ziobrowski (1993) Hedging foreign investments in US Real Estate with Currency Options. Journal of Real Estate Research, 8 (1), 27-54.

Ziobrowski, A and B. Ziobrowski (1995) Hedging Foreign Investments in US Real Estate with Forward Contracts. Journal of Property Valuation and Investment, 13 (1), 2243.

Ziobrowski, A. J., B. J. Ziobrowski, and S. Rosenberg (1997) Currency Swaps and International Real Estate Investment. Journal of the American Real Estate and Urban Economics Association, 25, 223-251. 
Exhibit 1: Expected Quarterly Office Returns (\%)

\begin{tabular}{|c|c|c|c|c|c|c|c|c|c|c|}
\hline \multirow[t]{2}{*}{ City } & \multicolumn{2}{|c|}{ Period 1} & \multicolumn{2}{|c|}{ Period 2} & \multicolumn{2}{|c|}{ Period 3} & \multicolumn{2}{|c|}{ Period 4} & \multicolumn{2}{|c|}{ Period 5} \\
\hline & (u) & (a) & (u) & (a) & (u) & (a) & (u) & (a) & (u) & (a) \\
\hline Hong Kong & 2.42 & 2.42 & 3.83 & 3.96 & 1.26 & 1.24 & -3.34 & -3.30 & 2.80 & 2.80 \\
\hline Singapore & 2.28 & 2.70 & 3.34 & 8.00 & 1.43 & 0.87 & -2.12 & -3.63 & 2.61 & 2.88 \\
\hline Kuala Lumpur & 1.38 & 0.98 & 3.58 & 3.73 & -0.40 & -1.74 & -2.64 & -9.06 & 0.35 & 0.64 \\
\hline Tokyo & 0.69 & 1.00 & 0.44 & 2.09 & 0.89 & 0.51 & -0.60 & -1.00 & 1.39 & 1.23 \\
\hline Melbourne & 0.70 & 0.33 & 0.34 & 0.06 & 0.98 & 0.93 & -2.66 & -0.18 & 2.20 & 1.02 \\
\hline Makati & 2.79 & 1.72 & 6.11 & 1.29 & 0.16 & -2.25 & 0.17 & -5.49 & 0.16 & 0.00 \\
\hline Jakarta & 3.58 & 0.07 & 3.11 & -5.28 & 3.94 & -2.43 & 12.26 & -25.19 & 1.17 & 1.21 \\
\hline
\end{tabular}

Note:

(u) - Currency-unadjusted (Foreign currency-denominated) returns

(a) - Currency-adjusted (USD-denominated) returns

Exhibit 2: Quarterly Expected Exchange Rate Returns (\%)

\begin{tabular}{||cccccc||}
\hline City & Period 1 & Period 2 & Period 3 & Period 4 & Period 5 \\
Hong Kong & 0.01 & 0.03 & 0.02 & 0.01 & 0.01 \\
Singapore & 0.40 & 1.07 & -0.54 & -1.36 & 0.27 \\
Kuala Lumpur & -0.40 & 0.03 & -1.34 & -3.90 & 0.30 \\
Tokyo & 0.31 & 1.15 & -0.38 & -1.01 & 0.16 \\
Melbourne & 0.37 & -0.21 & -0.05 & 1.49 & -1.16 \\
Makati & -1.04 & -0.68 & -2.41 & -4.83 & 0.16 \\
Jakarta & -3.38 & -2.04 & -6.12 & -17.91 & -0.04 \\
\hline
\end{tabular}


Exhibit 3: Expected Quarterly Office Standard Deviation (Risk) (\%) - CV in Brackets

\begin{tabular}{|c|c|c|c|c|c|c|c|c|c|c|}
\hline \multirow[t]{2}{*}{ City } & \multicolumn{2}{|c|}{ Period 1} & \multicolumn{2}{|c|}{ Period 2} & \multicolumn{2}{|c|}{ Period 3} & \multicolumn{2}{|c|}{ Period 4} & \multicolumn{2}{|c|}{ Period 5} \\
\hline & (u) & (a) & (u) & (a) & (u) & (a) & (u) & (a) & (u) & (a) \\
\hline Hong Kong & $\begin{array}{c}9.43 \\
(3.90)\end{array}$ & $\begin{array}{c}9.43 \\
(3.89)\end{array}$ & $\begin{array}{c}8.97 \\
(2.34)\end{array}$ & $\begin{array}{c}8.97 \\
(2.34)\end{array}$ & $\begin{array}{c}8.27 \\
(6.56)\end{array}$ & $\begin{array}{c}8.26 \\
(6.66)\end{array}$ & $\begin{array}{c}7.11 \\
(2.31)\end{array}$ & $\begin{array}{c}7.11 \\
(2.31)\end{array}$ & $\begin{array}{l}10.08 \\
(3.60)\end{array}$ & $\begin{array}{l}10.08 \\
(3.60)\end{array}$ \\
\hline Singapore & $\begin{array}{c}9.14 \\
(4.01)\end{array}$ & $\begin{array}{l}10.22 \\
(3.79)\end{array}$ & $\begin{array}{c}9.65 \\
(2.89)\end{array}$ & $\begin{array}{c}9.83 \\
(1.23)\end{array}$ & $\begin{array}{c}5.63 \\
(3.94) \\
\end{array}$ & $\begin{array}{l}5.57 \\
(6.40\end{array}$ & $\begin{array}{c}4.76 \\
(2.25)\end{array}$ & $\begin{array}{c}4.81 \\
(1.33)\end{array}$ & $\begin{array}{c}9.43 \\
(3.61)\end{array}$ & $\begin{array}{l}10.18 \\
(3.53\end{array}$ \\
\hline Kuala Lumpur & $\begin{array}{c}7.72 \\
(5.59) \\
\end{array}$ & $\begin{array}{c}8.57 \\
(8.74)\end{array}$ & $\begin{array}{c}9.27 \\
(2.59) \\
\end{array}$ & $\begin{array}{c}9.24 \\
(2.48) \\
\end{array}$ & $\begin{array}{c}6.56 \\
(16.40\end{array}$ & $\begin{array}{c}6.64 \\
(3.81) \\
\end{array}$ & $\begin{array}{c}4.77 \\
(1.81)\end{array}$ & $\begin{array}{l}5.42 \\
(0.6)\end{array}$ & $\begin{array}{c}5.83 \\
(16.65) \\
\end{array}$ & $\begin{array}{c}5.87 \\
(9.17) \\
\end{array}$ \\
\hline Tokyo & $\begin{array}{l}5.67 \\
(8.22\end{array}$ & $\begin{array}{c}8.41 \\
(8.41)\end{array}$ & $\begin{array}{c}5.06 \\
(11.5)\end{array}$ & $\begin{array}{c}5.26 \\
(2.52) \\
\end{array}$ & $\begin{array}{l}2.06 \\
(2.31)\end{array}$ & $\begin{array}{c}2.25 \\
(4.41)\end{array}$ & $\begin{array}{c}2.77 \\
(4.62)\end{array}$ & $\begin{array}{c}3.06 \\
(3.06)\end{array}$ & $\begin{array}{c}6.90 \\
(4.96)\end{array}$ & $\begin{array}{c}8.09 \\
(6.58)\end{array}$ \\
\hline Melbourne & $\begin{array}{l}5.30 \\
(7.57)\end{array}$ & $\begin{array}{c}7.54 \\
(22.85)\end{array}$ & $\begin{array}{c}3.24 \\
(9.53)\end{array}$ & $\begin{array}{c}3.23 \\
(53.83)\end{array}$ & $\begin{array}{c}7.45 \\
(7.60)\end{array}$ & $\begin{array}{c}7.51 \\
(8.08)\end{array}$ & $\begin{array}{l}11.01 \\
(4.14)\end{array}$ & $\begin{array}{c}10.95 \\
(60.83)\end{array}$ & $\begin{array}{c}3.64 \\
(1.65)\end{array}$ & $\begin{array}{c}7.39 \\
(7.25)\end{array}$ \\
\hline Makati & $\begin{array}{l}7.55 \\
(2.71\end{array}$ & $\begin{array}{c}9.23 \\
(5.37)\end{array}$ & $\begin{array}{c}8.01 \\
(1.31)\end{array}$ & $\begin{array}{c}7.96 \\
(6.17)\end{array}$ & $\begin{array}{c}3.94 \\
(24.62)\end{array}$ & $\begin{array}{c}4.09 \\
(1.82)\end{array}$ & $\begin{array}{c}3.76 \\
(22.12)\end{array}$ & $\begin{array}{c}3.92 \\
(0.71)\end{array}$ & $\begin{array}{c}6.67 \\
(41.69)\end{array}$ & $\begin{array}{c}8.26 \\
(\infty)\end{array}$ \\
\hline Jakarta & $\begin{array}{l}16.73 \\
(4.67)\end{array}$ & $\begin{array}{c}10.46 \\
(149.43)\end{array}$ & $\begin{array}{c}8.98 \\
(2.89)\end{array}$ & $\begin{array}{c}9.16 \\
(1.73)\end{array}$ & $\begin{array}{l}24.62 \\
(6.25)\end{array}$ & $\begin{array}{l}24.19 \\
(9.95)\end{array}$ & $\begin{array}{l}33.84 \\
(2.76)\end{array}$ & $\begin{array}{l}31.17 \\
(0.14)\end{array}$ & $\begin{array}{c}14.24 \\
(12.17)\end{array}$ & $\begin{array}{c}8.78 \\
(7.26)\end{array}$ \\
\hline
\end{tabular}

Note:

(u) - Currency-unadjusted (Foreign currency-denominated) standard deviation

(a) - Currency-adjusted (USD-denominated) standard deviation 
Exhibit 4: Statistical Test on Impact of Currency on Returns

\begin{tabular}{||c|c|c|c|c|c||}
\hline & \multicolumn{3}{|c|}{ Z - statistic } & \multicolumn{2}{c||}{ t - statistic } \\
\hline City & Period 1 & Period 2 & Period 3 & Period 4 & Period 5 \\
\hline Hong Kong & 0.000 & 0.001 & -0.001 & 0.000 & -0.001 \\
\hline Singapore & 0.003 & 0.019 & -0.029 & 0.013 & -0.039 \\
\hline Kuala Lumpur & -0.001 & -0.068 & 0.113 & 0.411 & -0.089 \\
\hline Tokyo & -0.021 & 0.035 & -0.124 & 0.061 & -0.307 \\
\hline Melbourne & -0.034 & -0.170 & 0.032 & -0.012 & 0.105 \\
\hline Makati & 0.000 & -0.093 & 0.194 & 0.391 & -0.080 \\
\hline Jakarta & 0.000 & -0.200 & 0.063 & 0.233 & -0.167 \\
\hline
\end{tabular}

Two-tailed z-statistic: $5 \%$ level of significance $(<-1.96$ or $>+1.96)$

Two-tailed t-statistic: $5 \%$ level of significance $(<-2.262$ or $>+2.262)$ 
Exhibit 5: Correlation Coefficients of Office Returns Before and After Currency Adjustments

\begin{tabular}{|c|c|c|c|c|c|c|c|c|c|c|}
\hline \multirow{2}{*}{ City } & \multicolumn{2}{|c|}{ Period 1} & \multicolumn{2}{|c|}{ Period 2} & \multicolumn{2}{|c|}{ Period 3} & \multicolumn{2}{|c|}{ Period 4} & \multicolumn{2}{|c|}{ Period 5} \\
\hline & Before & After & Before & After & Before & After & Before & After & Before & After \\
\hline Hong Kong-Singapore & 0.276 & 0.295 & -0.052 & -0.042 & 0.529 & 0.560 & 0.301 & -0.054 & 0.521 & 0.551 \\
\hline Hong Kong-Kuala Lumpur & 0.196 & 0.205 & -0.007 & -0.018 & 0.396 & 0.331 & 0.656 & $-0.227^{*}$ & 0.301 & 0.278 \\
\hline Hong Kong-Tokyo & 0.344 & 0.264 & -0.018 & 0.063 & 0.581 & 0.553 & 0.682 & $-0.128^{*}$ & 0.567 & 0.538 \\
\hline Hong Kong-Melbourne & 0.223 & 0.116 & -0.043 & -0.122 & 0.348 & 0.156 & 0.237 & 0.289 & 0.442 & 0.011 \\
\hline Hong Kong-Makati & 0.410 & 0.262 & 0.224 & 0.262 & 0.570 & 0.315 & 0.790 & 0.361 & 0.571 & 0.465 \\
\hline Hong Kong-Jakarta & -0.103 & -0.148 & 0.005 & -0.109 & -0.141 & -0.209 & -0.357 & 0.045 & 0.040 & 0.085 \\
\hline Singapore-Kuala Lumpur & 0.368 & 0.298 & 0.445 & 0.466 & 0.239 & 0.185 & 0.537 & 0.681 & 0.153 & 0.036 \\
\hline Singapore-Tokyo & 0.275 & 0.378 & 0.058 & 0.136 & 0.451 & 0.555 & 0.037 & -0.117 & 0.460 & 0.516 \\
\hline Singapore-Melbourne & 0.328 & 0.249 & 0.322 & 0.062 & 0.377 & 0.238 & 0.433 & -0.141 & 0.460 & 0.113 \\
\hline Singapore-Makati & 0.461 & 0.346 & 0.524 & 0.445 & 0.377 & 0.178 & 0.386 & 0.448 & 0.389 & 0.283 \\
\hline Singapore-Jakarta & 0.078 & 0.039 & 0.314 & 0.504 & 0.005 & 0.026 & 0.111 & 0.130 & 0.068 & 0.057 \\
\hline Kuala Lumpur-Tokyo & 0.144 & 0.216 & 0.278 & 0.093 & 0.051 & 0.144 & 0.538 & 0.268 & -0.034 & -0.031 \\
\hline Kuala Lumpur-Melbourne & 0.247 & 0.131 & 0.262 & 0.157 & 0.359 & 0.139 & 0.736 & $-0.215^{*}$ & 0.096 & -0.102 \\
\hline Kuala Lumpur-Makati & 0.387 & 0.361 & 0.432 & 0.320 & 0.113 & 0.165 & 0.396 & 0.066 & 0.077 & 0.071 \\
\hline Kuala Lumpur-Jakarta & 0.067 & -0.018 & 0.315 & 0.588 & -0.025 & -0.016 & -0.010 & 0.486 & 0.061 & 0.119 \\
\hline Tokyo-Melbourne & 0.313 & 0.080 & 0.578 & $0.183^{*}$ & 0.234 & -0.062 & 0.440 & 0.146 & 0.237 & -0.115 \\
\hline Tokyo-Makati & 0.369 & -0.129 & 0.076 & 0.031 & 0.743 & $-0.328^{*}$ & 0.603 & $0.014^{*}$ & 0.764 & $-0.058^{*}$ \\
\hline Tokyo-Jakarta & 0.041 & 0.079 & 0.327 & 0.046 & -0.038 & 0.020 & -0.054 & 0.522 & 0.006 & 0.065 \\
\hline Melbourne-Makati & 0.063 & -0.129 & 0.076 & 0.031 & 0.027 & -0.328 & 0.138 & 0.277 & -0.015 & -0.058 \\
\hline Melbourne-Jakarta & 0.234 & -0.052 & 0.327 & 0.046 & 0.204 & -0.141 & 0.379 & 0.464 & 0.140 & 0.087 \\
\hline Makati-Jakarta & 0.000 & 0.120 & 0.327 & 0.046 & 0.019 & 0.279 & -0.381 & -0.117 & 0.193 & 0.469 \\
\hline
\end{tabular}

Highlight indicates Cities with reduced correlation coefficients, after currency adjustment, for all or most periods.

* Changes in correlation coefficients (due to currency adjustment) that are significant at the 0.05 level of significance. 
Exhibit 6: Statistical Test on Impact of Currency Risk on Correlation Coefficients

\begin{tabular}{|c|c|c|c|c|c||}
\hline City & Period 1 & Period 2 & Period 3 & Period 4 & Period 5 \\
\hline Hong Kong-Singapore & -0.196 & 0.043 & -0.960 & -0.773 & -0.653 \\
Hong Kong-Kuala Lumpur & -0.425 & -0.046 & -1.197 & -2.156 & 0.019 \\
Hong Kong-Tokyo & -0.422 & 0.342 & -2.044 & -2.041 & -1.186 \\
Hong Kong-Melbourne & 0.084 & -0.340 & 0.539 & 0.118 & 0.238 \\
Hong Kong-Makati & 0.006 & 0.170 & -0.172 & -1.469 & -0.282 \\
Hong Kong-Jakarta & 0.369 & -0.485 & 0.409 & 0.887 & -0.642 \\
\hline Singapore-Kuala Lumpur & 0.430 & 0.111 & 0.672 & 0.491 & 0.274 \\
Singapore-Tokyo & 0.201 & 0.333 & -0.682 & -0.328 & -0.668 \\
Singapore-Melbourne & -1.069 & -1.152 & -0.740 & -1.285 & -0.261 \\
Singapore-Makati & -0.600 & -0.438 & -0.321 & 0.159 & -1.617 \\
Singapore-Jakarta & 0.412 & 0.972 & -0.555 & 0.041 & -0.189 \\
\hline Kuala Lumpur-Tokyo & -0.812 & -0.816 & -0.220 & -0.694 & 0.110 \\
Kuala Lumpur-Melbourne & -1.284 & -0.467 & -1.463 & -2.459 & -0.379 \\
Kuala Lumpur-Makati & -0.702 & -0.554 & -0.386 & -0.749 & -0.544 \\
Kuala Lumpur-Jakarta & 1.643 & 1.479 & 0.988 & 1.148 & 0.132 \\
\hline Tokyo-Melbourne & -1.686 & -2.012 & -1.595 & -0.691 & -2.062 \\
Tokyo-Makati & -0.206 & -0.190 & -0.437 & -1.450 & 1.148 \\
Tokyo-Jakarta & 0.243 & -1.245 & 0.828 & 1.343 & -0.973 \\
\hline Melbourne-Makati & -0.518 & -0.190 & 0.512 & 0.308 & -0.472 \\
Melbourne-Jakarta & -0.093 & -1.245 & -0.010 & 0.219 & -0.825 \\
\hline Makati-Jakarta & 0.439 & -1.245 & -0.515 & 0.602 & -0.945 \\
\hline Two-tailed z-statistic
\end{tabular}

Two-tailed z-statistic: $5 \%$ level of significance $(<-1.96$ or $>+1.96)$ 
Exhibit 7: Correlation Coefficients of Exchange Rate Returns

\begin{tabular}{||c|c|c|c|c|c||}
\hline City & Period 1 & Period 2 & Period 3 & Period 4 & Period 5 \\
\hline Hong Kong-Singapore & 0.122 & 0.089 & 0.109 & 0.208 & 0.110 \\
Hong Kong-Kuala Lumpur & 0.046 & 0.238 & -0.088 & -0.236 & 0.018 \\
Hong Kong-Tokyo & 0.150 & 0.129 & 0.161 & 0.290 & 0.142 \\
Hong Kong-Melbourne & -0.108 & -0.148 & -0.060 & -0.151 & -0.056 \\
Hong Kong-Makati & 0.082 & 0.061 & 0.087 & 0.338 & 0.013 \\
Hong Kong-Jakarta & 0.008 & -0.099 & 0.040 & 0.093 & 0.084 \\
\hline Singapore-Kuala Lumpur & 0.606 & 0.471 & 0.659 & 0.846 & 0.492 \\
Singapore-Tokyo & 0.629 & 0.654 & 0.638 & 0.578 & 0.711 \\
Singapore-Melbourne & -0.316 & -0.053 & -0.499 & -0.722 & -0.399 \\
Singapore-Makati & 0.202 & 0.257 & 0.125 & 0.281 & -0.293 \\
Singapore-Jakarta & 0.203 & 0.106 & 0.202 & 0.340 & -0.344 \\
\hline Kuala Lumpur-Tokyo & 0.278 & 0.403 & 0.266 & 0.389 & 0.225 \\
Kuala Lumpur-Melbourne & -0.199 & 0.075 & -0.302 & -0.579 & 0.041 \\
Kuala Lumpur-Makati & 0.183 & 0.156 & 0.167 & 0.119 & -0.640 \\
Kuala Lumpur-Jakarta & 0.208 & -0.082 & 0.226 & 0.148 & -0.529 \\
\hline Tokyo-Melbourne & -0.097 & 0.094 & -0.294 & -0.312 & -0.286 \\
Tokyo-Makati & 0.122 & 0.153 & 0.088 & 0.073 & 0.074 \\
Tokyo-Jakarta & 0.183 & 0.080 & 0.249 & 0.336 & 0.122 \\
\hline Melbourne-Makati & -0.269 & 0.153 & -0.314 & -0.319 & -0.323 \\
Melbourne-Jakarta & -0.222 & 0.080 & -0.362 & -0.643 & -0.140 \\
\hline Makati-Jakarta & 0.311 & 0.080 & 0.365 & 0.171 & 0.758 \\
\hline
\end{tabular}


Exhibit 8a: Efficient Frontier for Period 1 ( $2^{\text {nd }}$ quarter 1986 to $4^{\text {th }}$ quarter 2007)

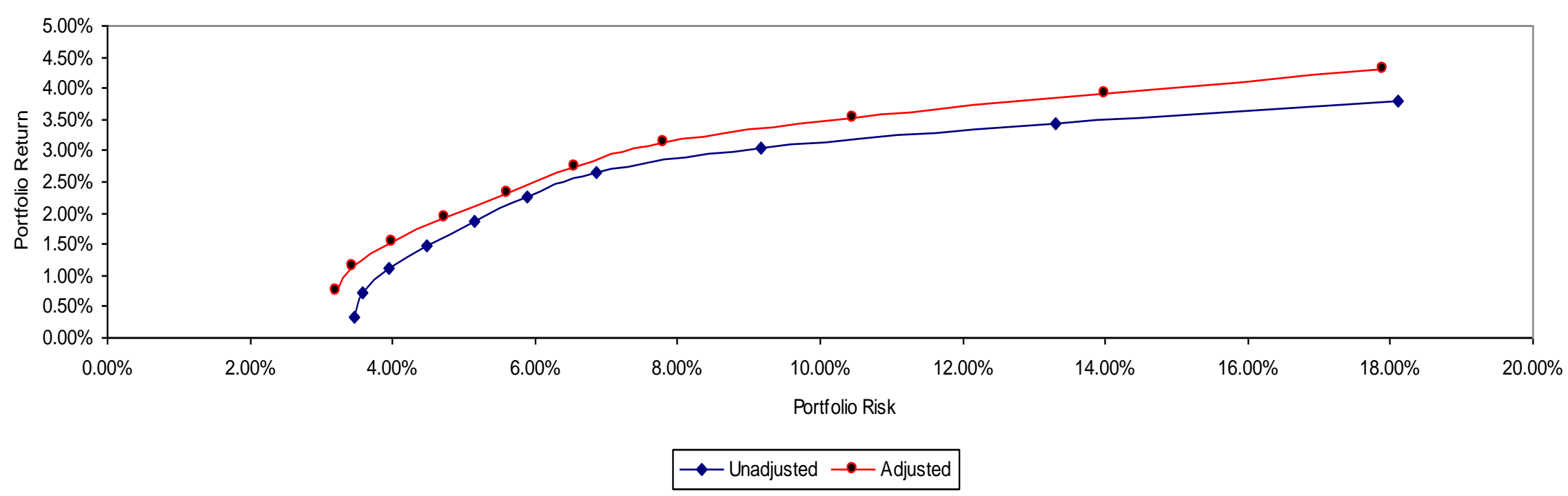


Exhibit 8b: Efficient Frontier for Period 4 ( $1^{\text {st }}$ quarter 1996 to $4^{\text {th }}$ quarter 1998)



$\multimap$ Unadjusted $\multimap-$ Adjusted 
Exhibit 8c: Efficient Frontier for Period 5 ( $1^{\text {st }}$ quarter 1999 to $4^{\text {th }}$ quarter 2007)

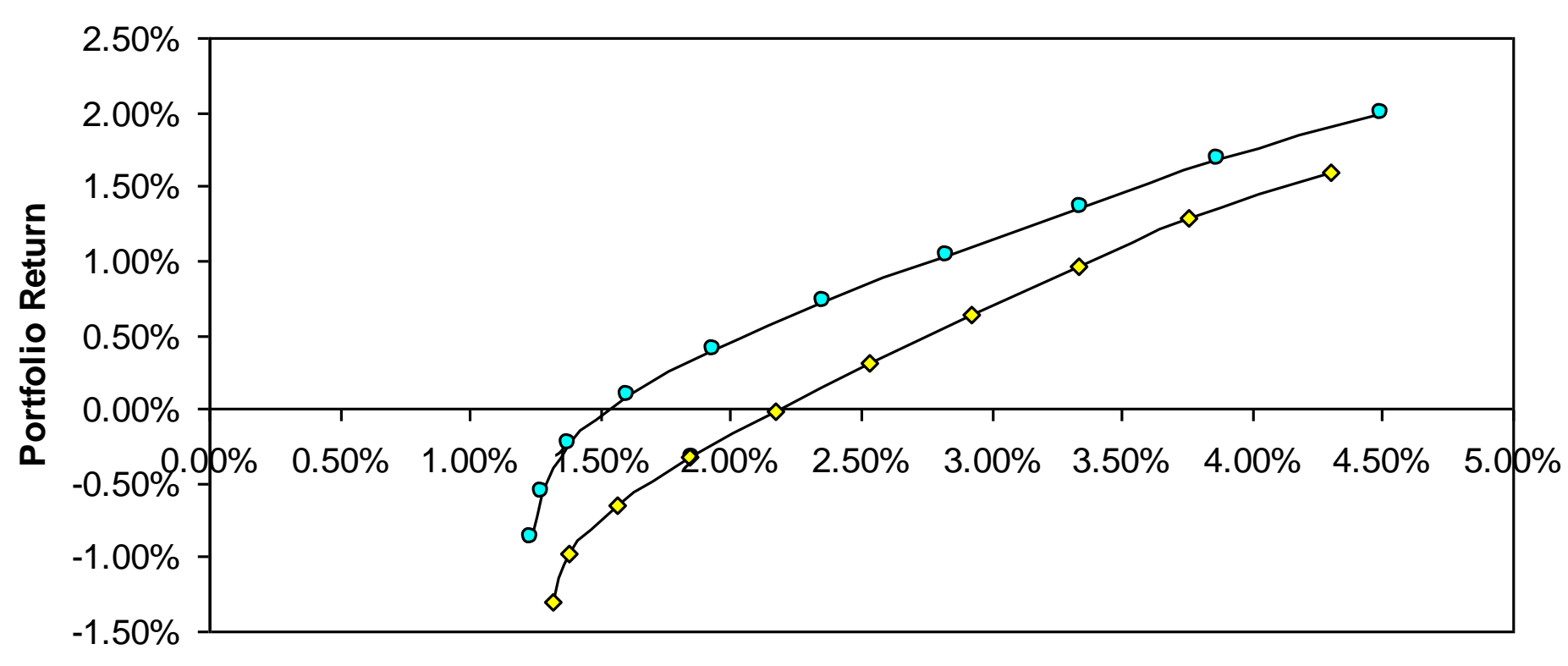

Portfolio Risk

$\multimap$ Unadjusted $\multimap-$ Adjusted 


\section{Exhibit 9: Paired Samples Test on Portfolio Return and Risk}

\begin{tabular}{|c|c|c|c|c|c|c|c|c|c|}
\hline & & \multicolumn{5}{|c|}{ Paired Differences } & \multirow{3}{*}{$\mathrm{t}$} & \multirow{3}{*}{$d f$} & \multirow{3}{*}{ Sig. (2-tailed) } \\
\hline & & \multirow[t]{2}{*}{ Mean } & \multirow[t]{2}{*}{$\begin{array}{c}\text { Std. } \\
\text { Deviation }\end{array}$} & \multirow[t]{2}{*}{$\begin{array}{l}\text { Std. Error } \\
\text { Mean }\end{array}$} & \multicolumn{2}{|c|}{$\begin{array}{l}95 \% \text { Confidence } \\
\text { Interval of the } \\
\text { Difference }\end{array}$} & & & \\
\hline & & & & & Lower & Upper & & & \\
\hline \multirow{2}{*}{$\begin{array}{c}\text { Period } 1 \text { (2nd } \\
\text { quarter } 1986 \text { - } \\
\text { 3rd quarter } \\
2007)\end{array}$} & Unadjusted - Adjusted & $-0.459 \%$ & $0.028 \%$ & $0.009 \%$ & $-0.479 \%$ & $-0.439 \%$ & & 9 & \\
\hline & Unadjusted - Adjusted & $-0.375 \%$ & $0.529 \%$ & $0.167 \%$ & $-0.753 \%$ & $0.003 \%$ & -2.242 & 9 & 0.052 \\
\hline \multirow{2}{*}{$\begin{array}{c}\text { Period } 2 \text { (2nd } \\
\text { quarter } 1986 \text { - } \\
\text { 4th quarter } \\
1995)\end{array}$} & Unadjusted - Adjusted & $-0.200 \%$ & $0.066 \%$ & $0.021 \%$ & $-0.248 \%$ & & -9.511 & 9 & 0.000 \\
\hline & Unadjusted - Adjusted & $0.235 \%$ & $0.109 \%$ & $0.034 \%$ & $0.157 \%$ & $0.313 \%$ & 6.840 & 9 & 0.000 \\
\hline \multirow{2}{*}{$\begin{array}{c}\text { Period } 3 \text { (1st } \\
\text { quarter } 1996 \text { - } \\
\text { 3rd quarter } \\
\text { 2007) }\end{array}$} & Unadjusted - Adjusted & $-0.462 \%$ & $0.292 \%$ & $0.092 \%$ & $-0.671 \%$ & $-0.253 \%$ & -5.001 & 9 & 0.001 \\
\hline & Unadjusted - Adjusted & $-1.239 \%$ & $1.346 \%$ & $0.426 \%$ & $-2.202 \%$ & $-0.276 \%$ & -2.911 & 9 & 0.017 \\
\hline \multirow{2}{*}{$\begin{array}{c}\text { Period } 4 \text { (1st } \\
\text { quarter } 1996 \text { - } \\
\text { 4th quarter } \\
\text { 1998) }\end{array}$} & Unadjusted - Adjusted & $-0.965 \%$ & $1.639 \%$ & $0.518 \%$ & $-2.137 \%$ & $0.207 \%$ & -1.862 & 9 & 0.095 \\
\hline & Unadjusted - Adjusted & $1.342 \%$ & $1.039 \%$ & $0.329 \%$ & $0.599 \%$ & $2.085 \%$ & 4.083 & 9 & 0.003 \\
\hline \multirow{2}{*}{$\begin{array}{c}\text { Period } 5 \text { (1st } \\
\text { quarter } 1999 \text { - } \\
\text { 3rd quarter } \\
\text { 2007) }\end{array}$} & Unadjusted - Adjusted & $0.041 \%$ & $0.377 \%$ & $0.119 \%$ & $-0.228 \%$ & $0.310 \%$ & 0.344 & 9 & 0.739 \\
\hline & Unadjusted - Adjusted & $0.303 \%$ & $0.179 \%$ & $0.057 \%$ & $0.175 \%$ & $0.431 \%$ & 5.341 & 9 & 0.000 \\
\hline
\end{tabular}


Exhibit 10a: Stochastic Dominance Analysis of Impact of Currency Risk on Portfolio Performance - Period 1

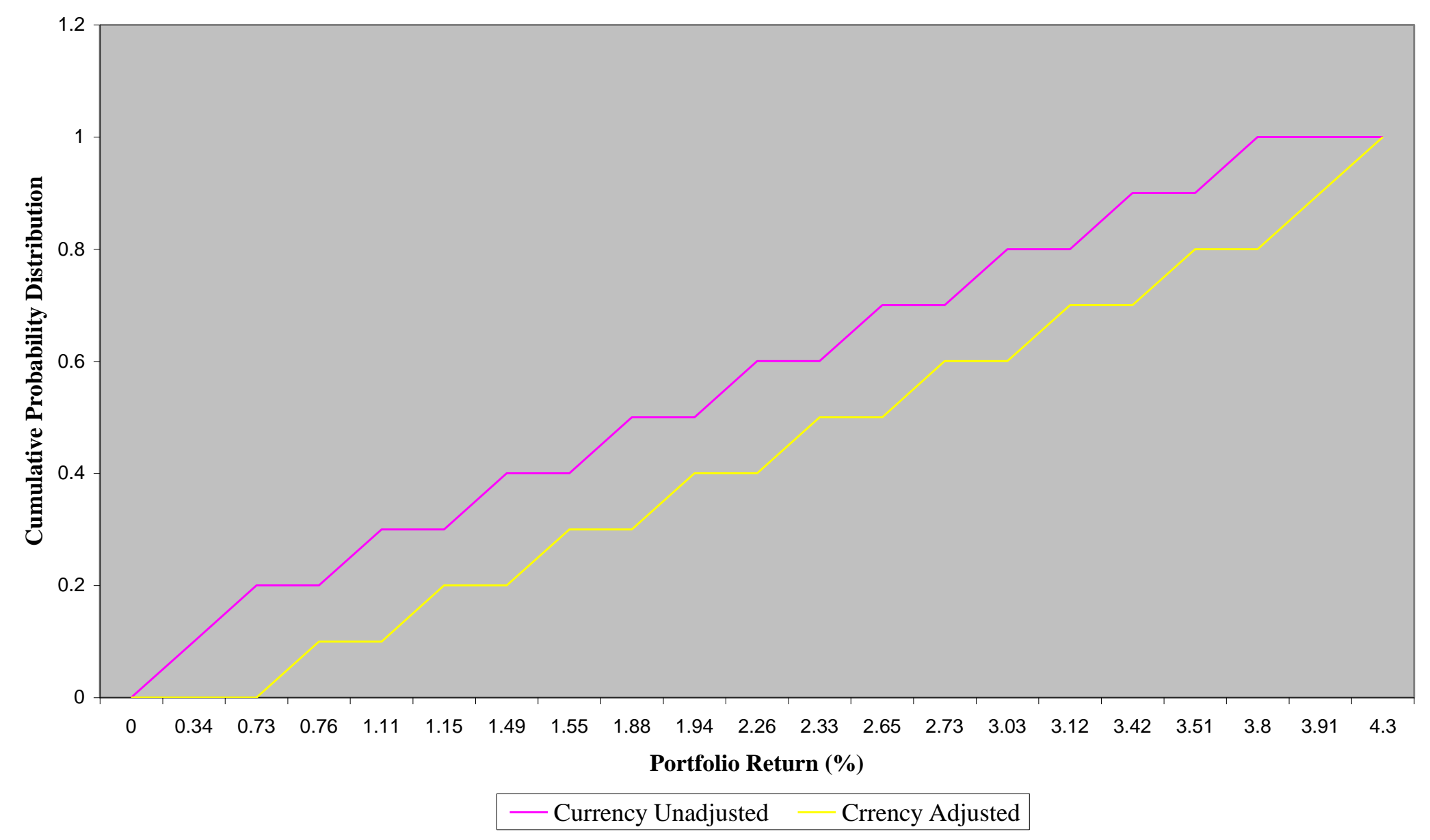


Exhibit 10b: Stochastic Dominance Analysis of Impact of Currency Risk on Portfolio Performance - Period 4

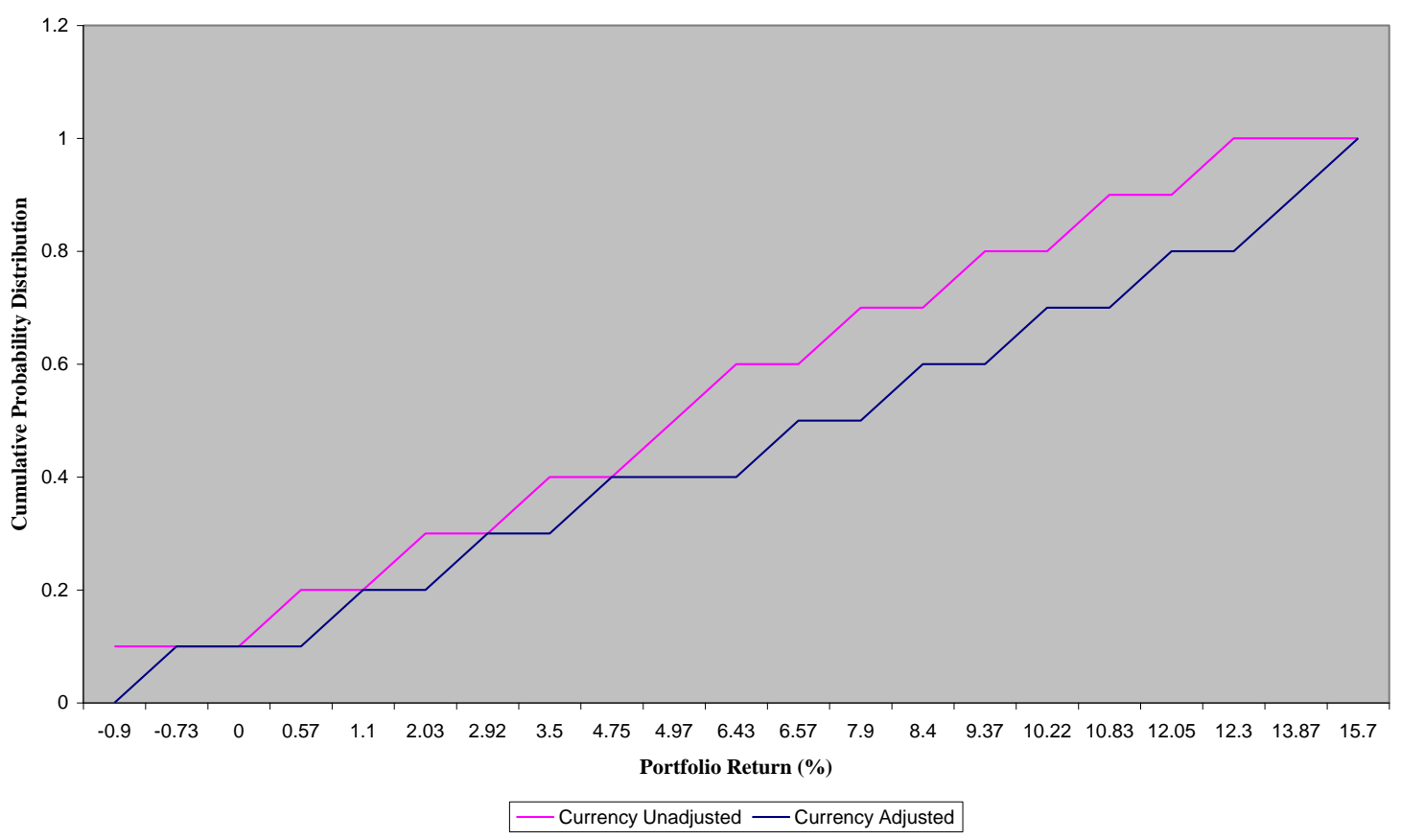

Exhibit 10c: Stochastic Dominance Analysis of Impact of Currency Risk on Portfolio Performance - Period 5

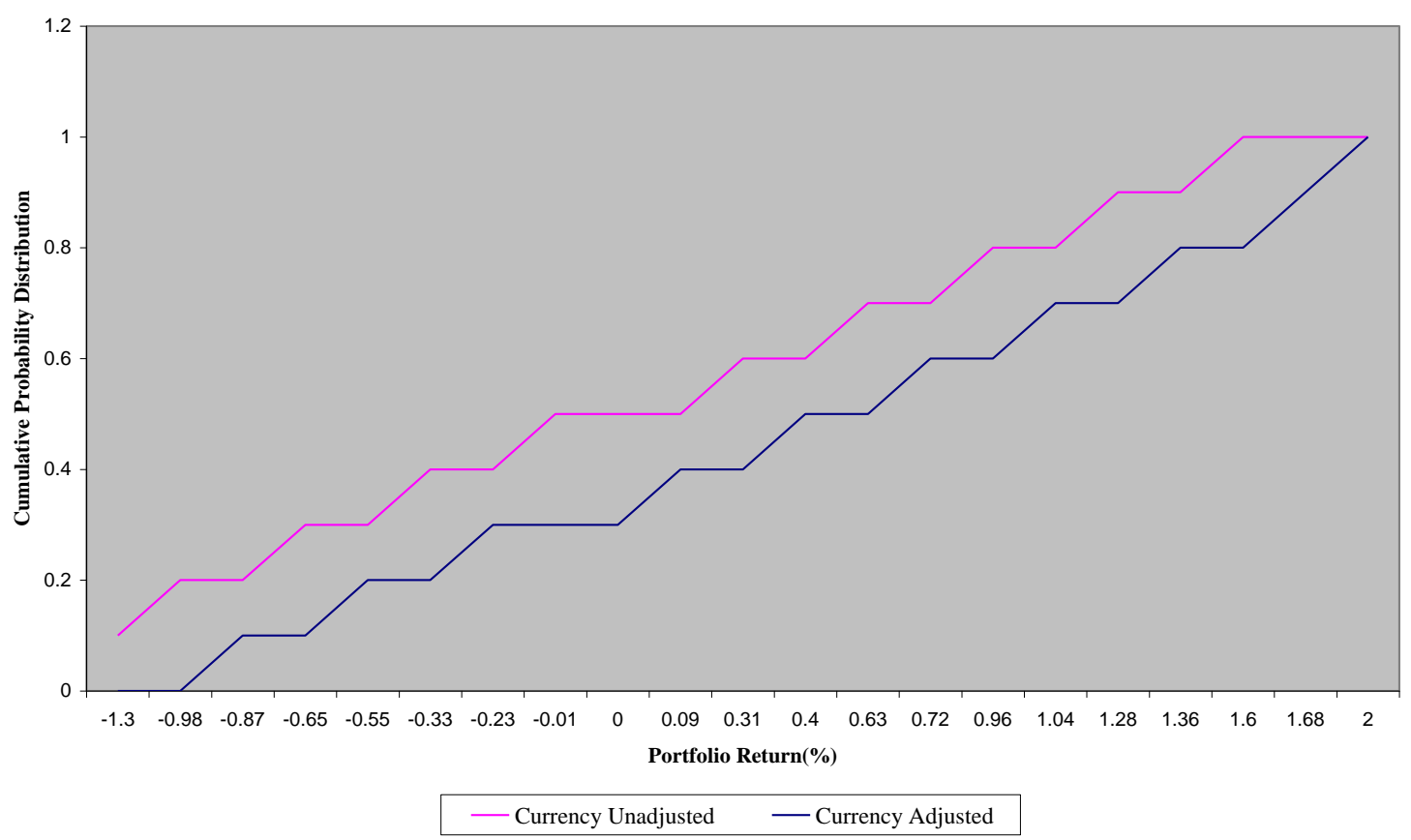

